\title{
APPLICATION OF DEMONSTRATION METHOD IN WRITING TEXT PROCEDURE AT SMA PASUNDAN 1 CIANJUR
}

\author{
Windy Dwi Sudiantika \\ SMA Pasundan I Cianjur 43216 \\ windydwisudiantika@yahoo.com
}

\begin{abstract}
This article discusses the significance of differences in the ability to write text of complex procedures before and after using the demonstration method and then to observe the interest of student learning in grade XI SMA Pasundan 1 Cianjur. The method used is a quasiexperimental study involving one study group by giving pretest as a preliminary test and postes as a final test to see the difference of learning result then use questionnaire to see interest in learning. Processing results of pretest and postes value, calculated using the help of SPSS application, from wilcoxon test results obtained 0.000 significance meaning less than 0.05 indicates the difference of learning outcomes before and after applied method of demonstration then student learning interest showed good response with 100\% answer want to relearn with this method. It was concluded that the application of demosntration method in writing text of complex procedure in class XI of Pasundan 1 Cianjur High School can give significant difference of learning result and student's learning interest showed good attitude.
\end{abstract}

Keywords: demonstration methods, complex text procedures.

\section{PENDAHULUAN}

Dalam proses pembelajaran, yang menjadi tujuan utama ialah siswa mampu memenuhi tujuan pembelajaran sesuai dengan kompetensi dasar yang ada. Akan tetapi, banyak pembelajaran yang tidak memenuhi tujuan pencapaian karena berbagai faktor.

Hal seperti itu yang tampak pada hasil observasi di SMA Pasundan 1 Cianjur dalam tema pembelajaran teks prosedur kompleks pada kompetensi dasar memproduksi atau menulis teks prosedur kompleks di kelas XI tahun ajar 2016-2017. Nilai siswa cenderung menurun, atau bahkan sulit mencapai nilai KKM (Kriteria Ketuntasan Minimal) yaitu 78 karena teks prosedur kompleks yang dibuatnya masih keliru dalam sistematika penulisan.

Dari permasalahan di atas, dilakukan penelitian eksperimen, semu dengan melibatkan satu kelas, dengan penggunaan metode demontrasi karena metode demonstrasi adalah metode mengajar dengan cara memperagakan barang, kejadian, aturan, dan urutan melakukan suatu kegiatan, baik secara langsung maupun melalui penggunaan media pengajaran yang relevan dengan pokok bahasan atau materi yang sedang disajikan (Syah, 2000:22). Dengan harapan penggunaan metode ini dapat membuat siswa lebih konsentrasi, tetap mengajak siswa aktif menyimak, berbicara, membaca dan menulis, tetapi tidak membosankan. Selain itu, diharapkan siswa mendapatkan pengalaman baru karena bertemu dengan narasumber secara langsung, membangun komunikasi yang baru karena berkenalan dengan nara sumber atau model yang baru.

Materi ajar yang dipilih ialah memproduksi teks prosedur kompleks yang berarti melakukan salah satu keterampilan berhasa yaitu menulis, yang menurut Nurgiantoro (1988:273) menulis adalah aktvitas aktif produktif, yaitu aktivitas mengahasilkan bahasa. Dalam penelitian ini siswa melakukan aktifivas produktif membuat teks prosedur kompleks. 
Teks prosedur sendiri merupakan teks yang berisi sebuah tata cara kerja. Ali (2000: 325) juga menjelaskan bahwa prosedur adalah tata cara kerja atau cara menjalankan sesuatu pekerjaan Dipilihnya materi ini karena sesuai fakta empiris, hasil belajar dan minat belajar siswa menurun dan sulit mencapai nilai KKM.

Melalui metode demonstrasi, nara sumber yang didatangkan akan mendemonstrasikan langkah membuat KTP (Kartu Tanda Penduduk). Dipilihnya topik pembelajaran menulis langkah pembuatan KTP karena pembelajaran ini juga termasuk pembelajaran kontekstual, manfaatnya dapat terasa di kehidupan nyata sehingga siswa menjadi lebih tahu bagaimana cara yang benar untuk memperoleh KTP.

Selain berfungsi sebagai kartu identitas, pentingnya memiliki KTP sudah diatur dalam Undang-Undang no. 23 tahun 2006 tentang Administrasi Kependudukan pasal 2 (a) yang berbunyi "Setiap Penduduk mempunyai hak untuk memperoleh Dokumen Kependudukan (KTP)". Peneliti juga semakin yakin dalam memilih topik ini karena bertepatan dengan usia siswa kelas XI yang masih 16 tahun sehingga ketika berusia 17 tahun atau sudah wajib memiliki kartu tanda penduduk tidak akan kebingungan dengan persyaratan dan tempat pembuatannya.

Pentingnya dilakukan penelitian ini untuk melihat dan menelaah peningkatan kemampuan menulis teks prosedur kompleks antara siswa yang belajar dengan metode demonstrasi dan siswa yang belajar dengan metode konvensional kemudian untuk melihat dan menelaah minat belajar siswa dengan metode demontrasi dan minat belajar siswa dengan metode konvensional. Untuk pelaksanaan penelitian yang maksimal, peneliti telah bekerjasama dengan pihak desa Mekarjaya untuk menghadirkan seorang narasumber yang kompeten dalam proses pembuatan KTP.

\section{METODE}

Metode yang digunakan saat penelitian adalah eksperimen semu (quasi eskperimental) dengan menggunakan pretest-posttest dengan tujuan mencari kemungkinan perbedaan yang signifikan sebelum menggunakan metode demosntarsi dan setelah menggunakan metode demonstrasi pada kemampuan siswa dalam menulis teks prosedur kompleks. Adapun pendapat ahli tentang metode penelitian eksperimen yaitu sebagai berikut.

Menurut Suryabrata (2012:88) penelitian eksperimen ialah penelitian yang bertujuan unutk menyelidiki kemungkinan saling hubungan sebab akibat dengan cara mengenakan kepada satu atau lebih kelompok eksperimental satu atau lebih kondisi perlakuan dan memperbandingkan hasilnya dengan satu atau lebih kelompok kontrol yang tidak dikenai kondisi perlakuan.

Bentuk instrumen yang digunakan dalam penelitian adalah lembar tes yang sama untuk pretes dan postes, kemudian lembar angket. Sebelum melaksanakan penelitian terlebih dahulu mempersiapkan silabus dan Rencana Pelaksanaan Pembelajaran (RPP) yang disesuaikan dengan pembelajaran dan aturan penyusunan RPP sekolah tersebut.

Sesuai dengan jadwal yang ditentukan, penelitian ini berlangsung dari tanggal 14 hingga 28 November 2016 dengan tahap pengujian intrumen tes dan angket terlebih dahulu oleh ahli kemudian pelaksanaan penelitian pada siswa kelas XI IPA 1 SMA Pasundan 1 Cianjur.

Pengolahan hasil pertes dan postes dari kedua kelompok menggunakan aplikasi SPSS. Sebelum mengetahui hasil analisis data pretes dan postes, terlebih dahulu dilakukan uji normalitas yang bertujuan untuk mengetahui apakah data hasil pretes dan postes tentang kemampuan menulis teks prosedur kompleks berasal dari populasi yang berdistribusi normal atau tidak. Dalam 
menghitung normalitas distribusi kelas-kelas yang menjadi sampel penelitian dilakukan uji sampel Kolmogorov Smirnov. Adapun perumusan hipotesis dalam uji normalitas distribusi populasi ini adalah sebagai berikut.

$\mathrm{H}_{0}$ : Sampel berasal dari populasi yang berdistribusi normal

$\mathrm{H}_{1}$ : Sampel berasal dari populasi yang berdistribusi tidak normal

Dapat diterimanya hipotesis uji normalitas dengan kriteria:

a) $\mathrm{H}_{0}$ diterima, apabila nilai signifikansi (Sig.) $\geq 0,05$

b) $\mathrm{H}_{0}$ ditolak, apabila nilai signifikansi (Sig.) $<0,05$

Kemudian jika salah satu data berdistribusi tidak normal maka ddilakukan uji non parametik Wilcoxon Signed Rank Test. Berikut hipotesis yang digunakan dalam uji non prametik ini:

$\mathrm{H}_{0}$ : Ada perbedaan yang signifikan kemampuan menulis teks prosedur kompleks siswa sebelum menggunakan metode demonstrasi dan setelah menggunakan metode demonstrasi.

$\mathrm{H}_{1}$ : Tidak ada perbedaan yang signifikan

kemampuan menulis teks prosedur kompleks siswa sebelum menggunakan metode demonstrasi dan setelah menggunakan metode demonstrasi.

Adapun kriteria pengujian hipotesisi non parametik Wilcoxon menggunakan taraf signifikansi 5\%, dengan pengambilan simpulan sebagai berikut.

a) $\mathrm{H}_{0}$ diterima, apabila nilai Sig (2-tailed) < 0,05 b) $\mathrm{H}_{0}$ ditolak, apabila nilai Sig (2-tailed) $\geq$ 0,05

\section{HASIL PENELITIAN}

\section{Signifikansi Perbedaan Hasil Belajar}

Hasil uji normalitas distribusi populasi data pretes disajikan dalam tabel berikut.

Tabel 1: Hasil Uji Normalitas Distribusi Populasi Data Pretes

\begin{tabular}{ccc} 
Data & \multicolumn{2}{c}{ Kolomogorov-Smirnov } \\
Signifikansi & Keterangan \\
\hdashline Pretes & 0,080 & Berdistribusi Normal \\
Poates & 0,000 & Tidak Berdistribusi \\
& & Normal
\end{tabular}

Berdasarkan hasil uji normalits distribusi populasi sampel pretes di atas, dapat dilihat bahwa nilai signifikansi diperoleh sebesar 0,080. Nilai signifikansi 0,080 lebih besar dari 0,05 sehingga $\mathrm{H}_{0}$ diterima. Oleh karena itu dapat disimpulkan bahwa data pretes berasal dari populasi yang berdistribusi normal.

Dalam menganalisis distribusi populasi data pretes juga dapat dilihat dalam Q-Q seperti tampak pada gambar 1 pada halaman berikut. Pada gambar dapat dilihat bahwa hampir seluruh titik yang tersebar berkumpul mendekati garis kenormalan dan hanya beberapa titik yang jaraknya jauh dan tersebar menjauhi garis kenormalan. Hal ini menunjukkan bahwa data pretes siswa berasal dari populasi yang berdistribusi normal.

Hasil uji normalits distribusi populasi sampel postes di atas, dapat dilihat bahwa nilai signifikansi diperoleh sebesar 0,000 . Nilai signifikansi 0,000 lebih kecil dari 0,05 sehingga $\mathrm{H}_{0}$ ditolak. Oleh karena itu dapat disimpulkan bahwa data postes berasal dari populasi yang tidak berdistribusi normal. Dalam menganalisis distribusi populasi data postes juga dapat dilihat dalam Q-Q Plot pada gambar 2. 


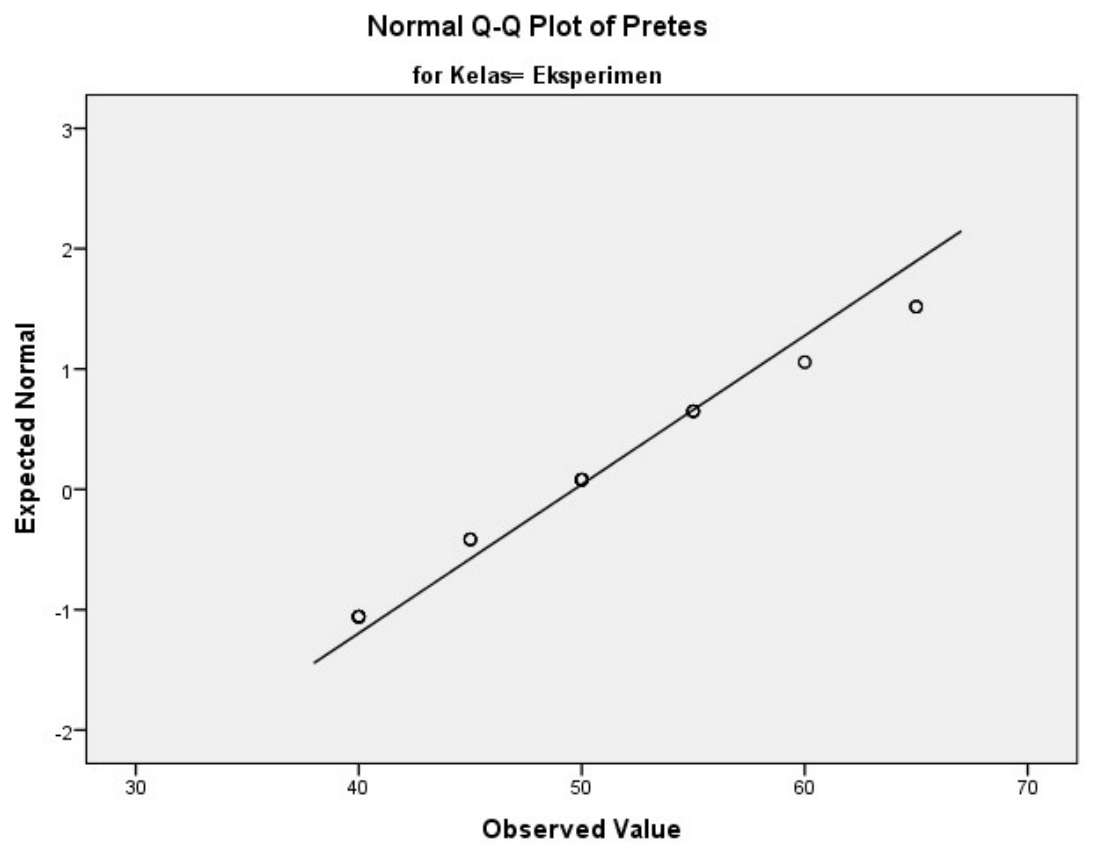

Gambar 1: Model Q-Q Plot Data Pretes

Pada gambar 2 di halaman berikut dapat dilihat bahwa hampir seluruh titik yang tersebar menjauhi garis kenormalan dan hanya satu titik yang jaraknya dekat dengan garis kenormalan. Hal ini menunjukkan bahwa data postes siswa berasal dari populasi yang tidak berdistribusi normal.

Pada penelitian ini data data pretes tidak berdistribusi normal sehingga dilakukan uji non parametik Wilcoxon Signed Rank Test. Berikut ini hasil dari uji non parametik Wilcoxon.

\section{Tabel 2: Test Statistics}

Sig.

Asymp. Sig. (2tailed)

Berdasarkan hasil uji non parametik wilcoxon diperoleh nilai sig. (2-tailed) sebesar 0,000 yang berarti kurang dari 0,05 (taraf signifikansi 5\%) sehingga $\mathrm{H}_{0}$ diterima.
Dengan demikian dapat disimpulkan bahwa adanya perbedaan yang signifikan kemampuan menulis teks prosedur kompleks siswa sebelum menggunakan metode demonstrasi dan setelah menggunakan metode demonstrasi. Tentunya perbedaan yang signifikan ini terjadi pada perbedaan nilai belajar yang lebih baik dari hasil nilai pretes ke hasil nilai postes menulis teks prosedur kompleks siswa.

Meningkatnya hasil belajar siswa dalam penelitian ini, jika dibandingkan dengan hasil penelitian Damayanti tentang Pengaruh Penggunaan Metode Demonstrasi Terhadap Kemampuan Siswa pada Pembelajaran Teks Prosedur Kompleks (2014: 78) menyatakan: adanya pengaruh peningkatan menulis teks prosedur kompleks setelah diterapkan metode belajar demonstarsi dengan media pendukung audio visual. Pengaruh ini dapat dilihat dengan nilai hasil belajar yang baik, dari 38 siswa $90 \%$ mengalami peningkatan signifikan dari nilai awal. Sedangkan $10 \%$ mengalami peningkatan namun masih berada pada nilai minimum ketuntasan. 


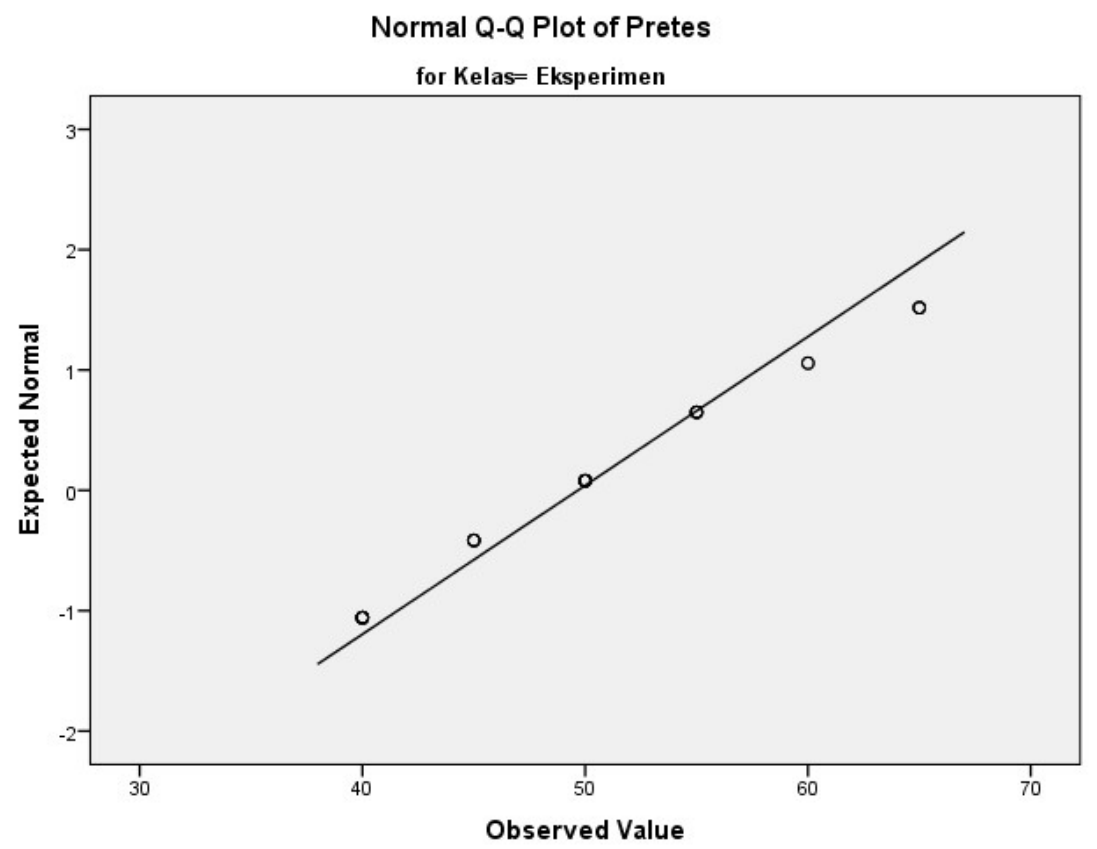

Gambar 2: Model Q-Q Plot Data Pretes

Dari hasil penelitian Sonia Damayanti, terdapat kesamaan dengan hasil penelitian ini, yaitu sama-sama menunjukan adanya peningkatan hasil belajar yang baik, setelah diterapkan metode demosntrasi. Hal ini semakin dibuktikan dengan teori ahli mengenai tujuan penggunaan metode demostrasi menurut Syah Muhibin (2006: 209) yaitu untuk memudahkan proses belajar mengajar digunakannya metode demonstrasi siswa lebih mudah memahami penyampaian pembelajaran. Selaras dengan pendapat tersebut, peneliti benar merasakan adanya kemudahan dalam proses belajaran ketika menggunakan metode demonstrasi. Maka secara keseluruhan dapat disimpulkan kembali bahwa adanya perbedaan yang signifikan kemampuan menulis teks prosedur kompleks siswa sebelum menggunakan metode demonstrasi dan setelah menggunakan metode demonstrasi.

\section{Minat Siswa Ketika Belajar}

Data hasil analisis minat belajar siswa diperoleh dari hasil pemberian angket. Pemberian dan pengisian angket ini dilakukan setelah pembelajaran selesai, dengan tujuan untuk mengetahui minat belajar menulis teks prosedur kompleks menggunakan metode Demonstrasi .

Setelah dihitung dan ditafsirkan, secara keseluruhan dapat disimpulkan bahwa minat belajar siswa menunjukan respon yang baik, salah satunya dari hasil jawaban angket yang menyatakan $100 \%$ siswa ingin belajar dengan metode demonstrasi lagi. Hal ini didukung dengan bukti adanya peningkatan hasil belajar yang signifikan antara hasil belajar sebelum diterapkan metode demosntrasi dengan hasil belajar sesudah diterapkan metode demonstrasi. Berarti hasil belajar yang baik didukung juga oleh minat belajar yang baik.

Besarnya minat belajar siswa dengan menggunakan metode demonstrasi dalam penelitian ini, jika dibandingkan dengan hasil 
penelitian Damayanti tentang Pengaruh Penggunaan Metode Demonstrasi Terhadap Kemampuan Siswa pada Pembelajaran Teks Prosedur Kompleks (2014: 84) menyatakan ketertarikan siswa terlihat jelas dengan banyaknya pertanyaan yang diajukan ketika pembelajaran, vidio pendek yang menayangkan tutorial hijab meningkatkan fokus siswa sebagai bahan jawaban untuk soal yang diajukan. Meski hasil penelitian Sonia Damayanti dinyatakan dengan kalimat $\mathrm{k}$ etertarikan belajar siswa sedangkan dalam penelitian ini dinyatakan dengan minat belajar siswa, namun terdapat kesamaan yaitu bertujuan menunjukan respon siswa setelah belajar dengan metode demostarsi. Kedua penelitian ini, membuktikan bahwa adanya kondisi minat belajar siswa yang baik setelah menggunakan metode demostrasi.

Dengan demikian, setelah dianalisis dan dibandingkan, metode demontrasi bisa dijadikan sebagai metode pembelajaran yang dapat membentuk minat atau semangat siswa menjadi lebih bergairah ketika belajar.

\section{SIMPULAN}

Berdasarkan hasil analisis data dari pengujian hipotesis yang dilakukan, beserta rumusan masalah yang disajikan, maka diperoleh simpulan sebagai berikut. Peningkatan kemampuan menulis teks prosedur kompleks siswa setelah dihitung menggunakan SPSS menunjukan dari hasil uji wilcoxon diperoleh 0,000 yang berarti kurang dari 0,05 menandakan adanya perbedaan hasil belajar yang signifikan sebelum dan sesudah diterapkan metode demonstrasi.

Setelah dibandingkan dengan hasil penelitian yang serupa dari Sonia Damayanti (2014: 78) menyatakan adanya pengaruh peningkatan menulis teks prosedur kompleks dari 38 siswa 90\% mengalami peningkatan signifikan dari nilai awal. Terdapat kesamaan dengan hasil penelitian ini, yaitu sama-sama menunjukan adanya peningkatan hasil belajar yang baik, setelah diterapkan metode demonstrasi.

Minat belajar siswa menunjukan respon yang baik atau positif, salah satunya dilihat dari hasil jawaban angket yang menyatakan $100 \%$ siswa ingin belajar dengan metode demonstrasi lagi. Hal ini didukung dengan bukti adanya peningkatan hasil belajar yang signifikan antara hasil belajar sebelum diterapkan metode demosntrasi dengan hasil belajar sesudah diterapkan metode demonstrasi.

Setelah dibandingkan dengan hasil penelitian yang serupa dari Sonia Damayanti (2014: 84) menyatakan ketertarikan siswa terlihat jelas dengan banyaknya pertanyaan yang diajukan ketika pembelajaran. Meski hasil penelitian Sonia Damayanti dinyatakan dengan kalimat ketertarikan belajar siswa sedangkan dalam penelitian ini dinyatakan dengan minat belajar siswa namun kedua penelitian ini, membuktikan bahwa adanya kondisi minat belajar siswa yang baik setelah menggunakan metode demostrasi.

Dari simpulan yang telah dikemukakan di atas, berkenaan dengan penelitian ini, disarankan untuk menggunakan Metode Pembelajaran Demonstrasi sebagai salah satu alternatif untuk penyelenggaraan kegiatan belajar mengajar di kelas karena dapat meningkatkan kemampuan menulis teks prosedur ompleks.

Bagi seorang pengajar yang hendak menggunakan Metode Pembelajaran Demonstrasi, disarankan untuk menyesuaikan narasumber atau model yang diundang atau digunakan dengan topik pada materi pembelajaran, kemudian disesuaikan dengan waktu pembelajaran sehingga dapat tercipta proses belajar mengajar yang efektif. 


\section{DAFTAR PUSTAKA}

Ali, Mohamad. 2000. Penelitian Kependidikan Prosedur \& Strategi. Jakarta: Angkasa.

Damayanti, Sonia. 2014. "Pengaruh Penggunaan Metode Demonstrasi Terhadap Kemampuan Siswa pada Pembelajaran Teks Prosedur Kompleks”. Skripsi Deskriptif: Universitas Pendidikan Ganesha. Bali (Tidak Dipublikasikan).

Nurgiantoro, Burhan. 1988. Penilaian dalam Pengajaran Bahasa dan Sastra. Yogyakarta: $\mathrm{BPFE}$

Republik Indonesia. 2006. Undang-Undang No. 23 Tahun 2006 tentang Administrasi Kependudukan. Sekretariat Negara: Indonesia.

Suryabrata, Sumadi. 2012. Metodologi Penelitian. Jakarta: Raja Grafindo Persada.

Syah, Muhibbin. 2000. Psikologi Belajar. Jakarta : Raja Grafindo Persada. 